\title{
THE DYNAMICS OF THE POPULATION \\ OF A STEPPE PERENNIAL SENECIO MACROPHYLLUS M.BIEB. DURING XEROTHERMIC GRASSLAND OVERGROWING
}

\author{
BOŻENNA CZARNECKA \\ Department of Ecology, Institute of Biology, \\ Maria Curie-Skłodowska University \\ Akademicka 19, 20-033 Lublin, Poland \\ e-mail: bozenna.czarnecka@poczta.umcs.lublin.pl \\ (Received: February 16, 2009. Accepted: June 9, 2009)
}

\begin{abstract}
The study aimed to determine the long-term changes of the Senecio macrophyllus M.BIEB. population traits: the abundance, reproduction mode, individual fecundity, seed rain and recruitment of new genets in the course of xerothermic grassland overgrowing. The study had also the applied goal: to estimate the chances of 'special care' species to survive in the changing environment without management regime for the maintenance of grassland. The model object was the island population of large-leaved ragwort on Biała Góra (the White Mountain) near Tomaszów Lubelski, South-East Poland. To achieve these aims I used the following sets of data: phytosociological relevés made in plant communities in an interval of 16-18 years; repeated elaboration of the numbers and life-stage structure of the population, both by non-surface and surface method; observation of plants' life cycle in 50 labelled genets; population reproduction and seed rain amounts. The area of an open xerothermic grassland decreased due to the process of overgrowing by bushes which was accompanied by the increasing coverage of forest and meadow herbs as well as monocotyledons, mainly Brachypodium pinnatum and Calamagrostis epigejos. The abundance of the $S$. macrophyllus population noticable diminished. The flowering mode has been changing during years from an oscillation to a chaotic type which caused the significant decreasing of the individual fecundity, population reproduction and seed rain. In last years it was reflected in the interruption of juveniles' recruitment.
\end{abstract}

KEY WORDS: xerothermic grassland, steppe plant, life-stage structure, reproduction mode, individual fecundity, seed rain.

\section{INTRODUCTION}

The population dynamics may be considered on different levels of its organization, that is, on individuals in the genetic sense (genets), originating from one zygote, and potentially independent parts of a genet (ramets), as well as in different aspects of population changes: numbers, size structure, life-stage structure, generative and/or vegetative reproduction, offspring survival, density and dispersal modes of individuals. Among traits affecting the reproduction of a population and, in consequence, the flux of seeds, the most important are the following: the share of genets (ramets) reaching the reproductive phase, their persistence in time and space, number of generative episodes during the individual life span, genet size and fecundity (Harper 1977; Crawley 1990; Stearns 1992; Silvertown and Lovett Doust 1993; Hutchings 1997; Falińska 1998; Begon et al. 2008). The flux of seeds (or other propagules) into and out of a unit of habitat, that is, the seed rain, determines the potential population of that habitat. The store of seeds bu- ried in soil (the seed bank) represents a vast dormant population accumulating over the years. Viable, dormant seeds can be regarded as a 'deposit account' (Harper 1977).

The population abundance, structure and organization is affected both by species features and by environmental conditions, so it may change simultaneously with changes in the populations of own and other species, and according to different spatial and temporal patterns of abiotic heterogeneity. Competition for resources, mainly for light, water and soil nutrients is often recognized as one of the most important factors structuring the plant size and fecundity (Hara 1988; Silvertown and Lovett Doust 1993; Hutchings 1997). The dominant process of competition is occupation of space. The competitive ability of plants varies with their age or life stage, particularly in clonal plants (Grubb 1977; Blair 2001; Weiner 2004).

The environmental heterogeneity is strengthened by disturbances of various scales and intensities. According to Picket and White (1985) disturbances are understood as 'relatively discrete events in time that disrupt an ecosy- 
stem, community, or population structure and change resources, substrate availability, or the physical environment', thus, provide a more heterogeneous environment (Grubb 1977; Harper 1977). It may be said with high probability that the more natural and stable a given ecological system, the more resilient to disturbances it is, and, on the other hand, the more unstable a given system, the more susceptible it is to different events that remove organisms and open up space (gap formation) which can be colonized by individuals of the same or different species.

Among plant communities in Poland, grasslands, apart from the ones in the high mountains, are considered as semi-natural. Xerothermic grasslands on calcareous rocks, classified as Festuco-Brometea class have a special position (Matuszkiewicz 2005). In western and central Europe they are extra-zonal communities, originating from primeval forests' cutting. Their presence is conditioned by a peculiar combination of soil and climatic factors, and they are maintained due to different forms of land use (grazing by sheep or cattle, mowing, burning). Abandonment of traditional use of xerothermic grasslands in the last decades followed by shrub encroachment has resulted in a dramatic decrease in their area, and in consequence, in reducing the species and phytocoenotic diversity (Bobbink and Willems 1987; Dzwonko and Loster 1992; Hurst and John 1998; Bąba 2003; Loster and Gawroński 2005).

The paper reports a part of long-term studies of the island population of Senecio macrophyllus which has been conducted since 1988. This research focused on the following aims: 1) to assess the changes in xerothermic vegetation in the course of bush encroachment and their effect on the population fate; 2) to evaluate population numbers and variability of share of reproductive genets (ramets), and individual fecundity; 3 ) to find out whether changing habitat conditions enable the formation of sufficient seed rain and effective recruitment of new genets in the population. My study had also the applied goal: to estimate the chances of 'special care' species to survive in the changing environment without management regime for the maintenance of xerothermic grassland.

\section{MATERIAL AND METHODS}

\section{Study site and species}

The model population of the species has been studied on Biała Góra (the White Mountain) near Tomaszów Lubelski, South-East Poland. The White Mt. (50²8'N, 2329'E; $349 \mathrm{~m}$ a.s.1.) is a vast, parabolic hill built of the cretaceous marles and loesses. Shallow rendzinas have been formed on that substratum with the alkaline soil reaction $(\mathrm{pH}=7.4-$ -7.8). The south-western, western and north-western slopes of different gradient $\left(10-45^{\circ}\right)$ are overgrown with the mosaics of vegetation (Czarnecka 1994, 1995):

- xerothermic grasslands of the alliance Cirsio-Brachypodion pinnati, the class Festuco-Brometea, both patches of low, loose grassland dominated by Aster amellus, Carex flacca and Teucrium chamaedrys, and tall, dense ones with Brachypodium pinnatum and Peucedanum cervaria as dominants;

- xerothermic bushes of the class Rhamno-Prunetea, formed of Prunus spinosa, Cornus sanguinea, Corylus avellana, Crataegus monogyna, Rhamnus catharticus accompa- nied by communities of tall herbs belonging to the class Trifolio-Geranietea sanquinei;

- beech-hornbeam forests of the class Querco-Fagetea, with admixture of Pinus sylvestris and other leafy species.

The White Mt. is a site of occurrence of many plant species subjected to strict or partial protection: Anemone sylvestris, Cephalanthera damasonium, Cimicifuga europaea, Clematis recta, Epipactis helleborine, Hedera helix, Lilium martagon, Linum flavum and others (Czarnecka 1994). For the unique values of this area, a part of the White Mt. hill (33.7 ha) was established as an ecological unit in 1996.

Among the most valuable elements of the White Mt.'s flora is a rare, steppe ragwort, Senecio macrophyllus M. BIEB., Asteraceae, formerly known as S. doria subsp. umbrosus or S. umbrosus Waldst. et Kit. (Chater and Walters 1976; Czarnecka et al. 1993; Grulich and Hodálova 1994; Czarnecka and Kucharczyk 2001). S. macrophyllus is a large, rhizomatous, iteroparous (polycarpic) plant with an erect flowering stem up to $190 \mathrm{~cm}$ high and inflorescence (subcorymb) consisting of numerous heads. It produces large amount of achenes which are equipped with white pappus enabling dispersion by wind. S. macrophyllus is characterized by dominance of generative reproduction, a very slow rate of individual development and a long life span of genet, over 30 years (Czarnecka 1995, 2006; B. Czarnecka, unpbl. data).

\section{Vegetation study}

Phytosociological relevés in different plant communities with presence of Senecio macrophyllus were done twice, in the same study sites: in 1990-1992 and 2006-2008, that is, with an interval of 16-18 years. Eleven-degree scale was used, with + symbol for the species coverage less than $5 \%$, 1 - for cover of $5-10 \%, 2$ - for $10-20 \%, \ldots, 10$ - for 90 $-100 \%$. Particular species were attributed to proper syntaxonomic units (phytosociological classes) according to Matuszkiewicz (2005). Six patches of the vegetation were chosen for further detailed analysis. They were situated in the south-eastern part of the hill where the process of bush encroachment was the most advanced.

\section{Population study}

The abundance and life-stage structure of the Senecio macrophyllus population were studied many times, both by non-surface and surface method (Kwiatkowska and Symonides 1978). The non-surface method - wandering quarter method - was used five times, in the years: 1990, 1998, 2000, 2003, 2006, and aimed to evaluate the above-mentioned characteristics of the population at a large scale. Each time the genets of $S$. macrophyllus were counted along a line transect ca. $70 \mathrm{~m}$ long leading from the ragwort individual nearest the outskirt of woodland overgrowing the upper part of the hill to the slope footstep.

Using the surface method, six permanent plots were established in vegetation patches differing in terms of floristic composition, soil and microclimatic conditions. The detailed site description was done by Czarnecka (1995). Each plot was in a shape of belt transect divided into $2 \times 2 \mathrm{~m} \mathrm{squ}-$ ares. For detail analysis of the population changes in a small scale I chose one permanent plot for the same reasons as in the case of vegetation changes. At the beginning of the study that transect $\left(2 \times 12 \mathrm{~m}=24 \mathrm{~m}^{2}\right)$ was overgrown with low, loose and sun-exposed grassland. The dominant 
species, S. macrophyllus ( $60 \%$ of coverage), was accompanied first of all by Carex flacca, Salvia verticillata, Teucrium chamaedrys and Aster amellus. During the period of 1990-2008 the abundance and life-stage structure of the population was studied 13 times, that is, in the years: 1990-1992, 1995, 1998 and 2001-2008. The life cycle of plants was observed in 50 individual genets situated within the transect. At the time of labelling (summer 1989), the plants were at different ontogenic stages.

In both methods I took into account the following life stages of genets (or ramets), according to proposals of Gatsuk et al. (1980): juvenile (i); immature (im), that is, young vegetative; mature vegetative (v), i.e. pre-reproductive (= virginile) together with secondary vegetative, so going through the resting phase after flowering or between subsequent reproductive episodes; generative $(\mathrm{g})$ - flowering and fruiting plants. For evaluation of changes of flowering pattern of the population S. macrophyllus I used only the data on numbers of mature ramets (i.e. vegetative and generative).

The individual fecundity (IF), that is, the average number of propagules (achenes) produced by a genet is a product of the following traits: IF = propagule number per one head $x$ head number per one ramet $x$ ramet number per one genet. The average number of achenes, further called 'seeds', were calculated on the basis of 30 heads sampled randomly from the whole study slope in 1990 . Numbers of heads per ramet as well as ramets per one genet were counted six times (1990, 1992, 1993, 1999, 2003, 2006). Seed rain (SR) was calculated as a product of individual fecundity and number of generative ramets per one hectare.

The results were statistically described in terms of mean values $(\overline{\mathrm{X}})$, standard devations (SD) and coefficients of variation $(\mathrm{CV})$. The two-side test for differences of two structure indices (i.e. the U-test) was used to check the significance of differences in the proportion of juvenile ramets (= genets) in the total number of ramets in the population as well as the share of generative ramets in the number of mature ramets between consecutive study years. The significance of differences between mean number of heads per one ramet was analyzed by means of the non-parametric Friedman test.

\section{RESULTS}

\section{Changes of vegetation}

During the 18-year-study period different changes of the plant cover have been observed on the slopes of the White Mt. hill (Table 1). The area of open xerothermic grassland decreased due to the process of overgrowing by bushes composed of Prunus spinosa, Rosa canina, Crataegus monogyna, Cornus sanguinea, so the species characteristic for the class Rhamno-Prunetea, with the admixture of Pinus sylvestris. Some of the pine individuals died during the study period. Numerous juvenile and grow-up individuals of shrubs and trees appeared in the grassland area, and a several meter-wide belt of brushwood has developed along the footstep of slopes. Shrub encroachment was accompanied by the increasing coverage of herbs representing the classes Trifolio-Geranietea sanquinei and Molinio-Arrhenatheretea, and some other species (Tussilago farfara, Convolvulus arvensis, Hypericum perforatum). From the side of the beech-hornbeam forest together with young individuals of shrubs and trees, some woodland plants entered the open habitat (e.g. Hepatica nobilis, Asarum europaeum, Melica nutans, Carex digitata).

The participation of some valuable components of xerothermic grasslands has been decreased, for example Aster amellus and Teucrium chamaedrys (Table 1). The coverage of Senecio macrophyllus in particular patches also changed and diminished from $60 \%$ in 1990 to $40 \%$ in 2008 within the permanent plot. Simultaneously, the increase of coverage of monocotyledons was noticeable, mainly Brachypodium pinnatum and Calamagrostis epigejos. The first species is an immanent element of xerothermic grasslands but few large clumps of that grass, absent in the early 1990-ties, appeared. The second grass colonized the study area from adjacent, abandoned fields, where it has become more abundant within the last decade.

\section{Changes in numbers and life-stage structure of the population}

The examined population of the Senecio macrophyllus exhibited considerable dynamics in the abundance and density both at a large scale (Table 2, Fig. 1A) and at a small scale (Fig. 2A), and the intensity of changes depended on the scale adopted.

The transformation of the population abundance and lifestage structure of ramets was mainly reflected at a small scale, that is, within the permanent plot. The total number of ramets dropped as much as 10 times during the study period (Fig. 2A). I observed three steps of transition decreasing: between 1995 and 1998 (by a factor of 1.6), between 2001 and 2002 (2.3 times), and the last one, between 2006 and 2007 (almost two times). At the beginning of the study (1990-1992) the population abundance was relatively stable and characterized by a prevalence of the share of young ramets (= genets), i.e. juvenile and immature altogether, over the share of mature ramets, that pointed to the expansion phase of the population. The differences in the contribution of juveniles were not significant. For the next long period (1995-2003) the ramet dynamics exhibited an oscillation type, and the proportion of immature vs. mature plants was more balanced and typical for a population in the phase of fluctuation growth. The percentage of juveniles changed significantly (U-test; $0.0001<\mathrm{P}<0.05$ ), except some cases between the consecutive seasons during the study periods: 1995-1998, 2001-2003, and 2004-2008. Since 2004 to the end of the study the lack of juvenile genets' recruitment was reflected in the dramatic decreasing of the population numbers. At a large scale, that is, on the whole slope, differences in the share of juvenile genets were significant between 1990 and the subsequent study seasons $(0.01<\mathrm{P}<0.05)$ with exception of 2000 ; during the rest of periods significant difference was found only for the years 2000 and $2003(\mathrm{P}=0.0001)$.

\section{Changes of population reproduction and seed rain amounts}

The percentage of flowering ramets changed over all the time. The flowering pattern was less variable at a large scale than at a small scale. The studies on contribution of generative shoots made along a line transect in several-year intervals showed the gradual weakening of the flowering with time - from ca. $24.2 \%$ to $7.9 \%$ (Fig. 1B). As it concerns the large-scale study, significant differences in the fraction of generative ramets there were between the first 
TABLE 1. Vegetation changes in the years 1990-2008. Species names according to Mirek et al. (2002). Classes according to Matuszkiewicz (2005): V-P _ Vaccinio-Piceetea; R-P - Rhamno-Prunetea; F-B - Festuco-Brometea; M-A - Molinio-Arrhenatheretea; T-G - Trifolio-Geranietea; Q-P - Querco-Fagetea; Epa - Epilobietea angustifolii.

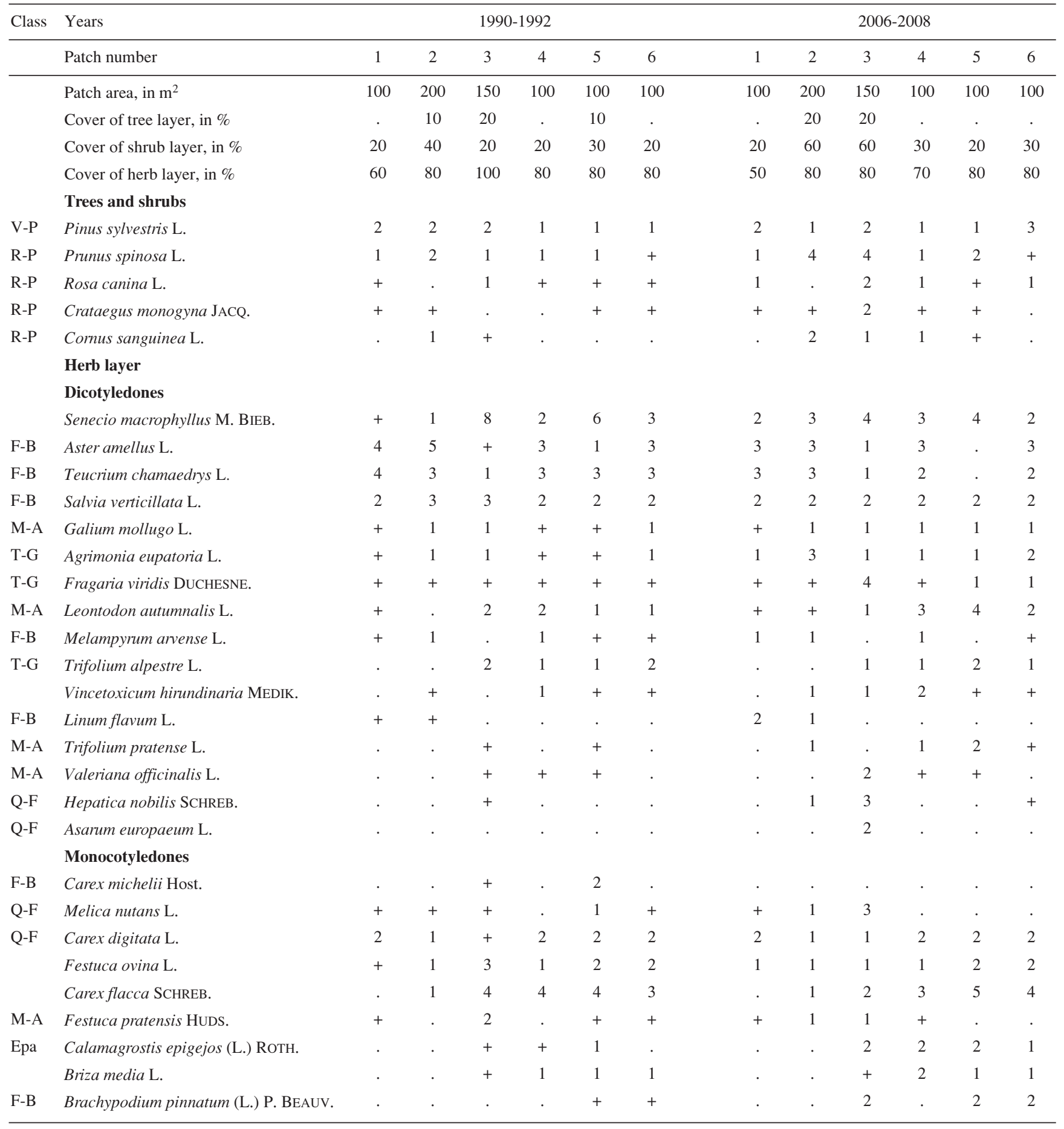

TABLE 2. Changes of the Senecio macrophyllus population density and share of generative ramets. Data collected by the wandering quarter method.

\begin{tabular}{ccccc}
\hline Year & $\begin{array}{c}\text { Total } \\
\text { number } \\
\text { of ramets } \\
\cdot 100 \mathrm{~m}^{-2}\end{array}$ & $\begin{array}{c}\text { Share } \\
\text { of generative } \\
\text { ramets [\%] }\end{array}$ & $\begin{array}{c}\text { Number } \\
\text { of generative } \\
\text { ramets } \cdot 100 \mathrm{~m}^{-2}\end{array}$ & $\begin{array}{c}\text { Number } \\
\text { of generative } \\
\text { ramets } \cdot 1 \mathrm{ha}^{-2}\end{array}$ \\
\hline 1990 & 73 & 11.3 & 8 & 800 \\
1998 & 237 & 8.5 & 20 & 2000 \\
2000 & 250 & 4.8 & 12 & 1200 \\
2003 & 376 & 4.7 & 18 & 1800 \\
2006 & 208 & 3.6 & 7 & 700 \\
\hline
\end{tabular}

and the last study years as well as between 1998 and the next periods (U-test; $0.01<\mathrm{P}<0.05$ ). Within the permanent plot the proportion of flowering ramets varied in a very wide range (Fig. 2B): from $30.3 \%$ of all mature ramets in 1998 to $0 \%$ in 2006 (so-called 'deaf year'), and in three previous seasons it oscillated around $1 \%$ only. In the years 1990-2002 the pattern of flowering seemed to be of a fluctuation character, and then it started to be a more chaotic. Thus, at the small scale the differences in the percentage of generative ramets between years were not so unequivocal (Table 3).

Among the 50 genets labelled in 1989 within the permanent area there were: three generative, 38 mature vegetati- 
A
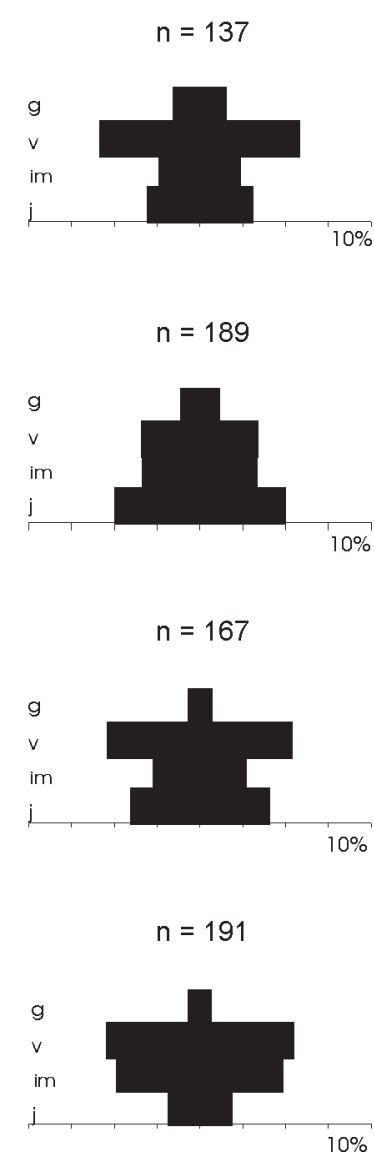

2003
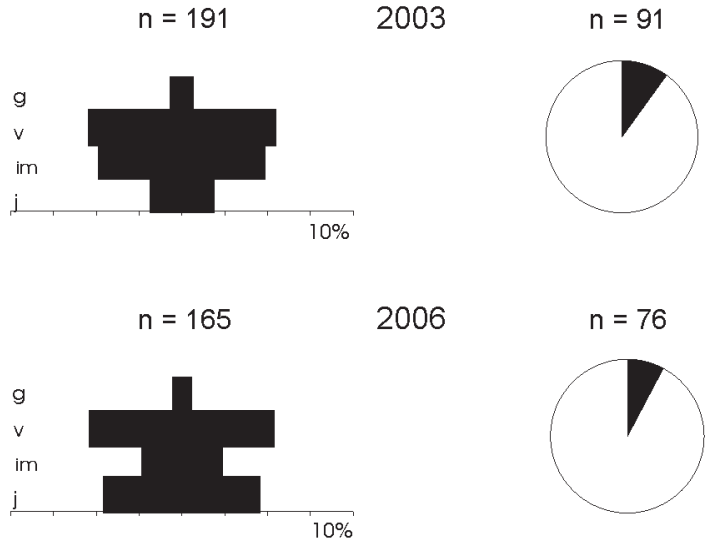

2006

$10 \%$

Fig. 1. Changes of the Senecio macrophyllus population at a large scale: A - life-stage structure; B - flowering pattern, i.e. a share of floweting ramets (black fields) in total number of mature ramets; $n$ - number of ramets; $\mathrm{j}$ - juvenile ramets (= genets); im - immature ramets (= genets); $\mathrm{v}$ mature vegetative ramets; $g$ - generative ramets. Data collected by the wandering quarter method.

ve (virginile and post-reproductive plants) and nine young vegetative ones (juvenile and immature, altogether). In the subsequent 20 seasons 47 plants flowered, which means that the original group of reproductive plants was joined by the following 44 plants which were in various vegetative stages at the beginning of the study. Out of that 47 genets, the majority of $33(70.2 \%)$ flowered one to three times; the remaining ones flowered four to six times (Fig. 3). The average value was $2.7 \pm 1.6(\mathrm{CV}=58.1 \%)$. In total, I observed 127 reproductive episodes which were rarer and rarer with time. During the last six years only three episodes happened there, one every second year, including the case of flowering after a 15-year break. It was the maximum compared to the earlier resting periods, ranging from one to nine years. At the same time there were eight breaks that had already lasted 10-15 years. Of the 50 labelled plants,
$18(36 \%)$ were still alive in 2008 . The genet survival differed between the groups of mature and young individuals ( $41.5 \%$ vs. $11.0 \%$, respectively). The weakening of the flowering with time confirmed the tendency observed both on the whole study slope and within the permanent plot (Figs $1 \mathrm{~B}$ and $2 \mathrm{~B})$.

The average propagule number per one head was $38.7 \pm 5.0$ with very low coefficient of variation $(\mathrm{CV}=12.8 \%)$. For the number of heads per single flowering ramet (IF), the mean value was the highest at the beginning of the study (ca. 61-62 heads) and the lowest in 1999 (27.7 \pm 7.6$)$; in the remaining study seasons the value ranged between 35 and 37 heads (Table 4). The maximum numbers - over 90 heads per one ramet - I noted in the years 1990-1992. This feature had greater variability: $27.4 \%<\mathrm{CV}<54.4 \%$. There were significant differences in the number of heads between the years (Friedman test; $\chi^{2}=$ 33.62; $\mathrm{P}<0.0001)$. Seed rain $(\mathrm{SR})$ in the subsequent periods was affected first of all by density and share of generative ramets in the population studied (Table 2 and 4). In the years 1990 and 2003 the SR was at the level of 1922000 and 2605000 seeds per 1 ha, respectively, and then it dropped to only 965000 seeds per 1 ha in 2006 .

\section{DISCUSSION}

The changes in abundance, generative reproduction and seed rain size in the Senecio macrophyllus population on the White Mt. were caused by both abiotic and biotic factors that influence them in different ways. Open grassland overgrown by trees and shrubs changed the microclimatic conditions and was followed by shade-tolerant woodland species. That process was confirmed by J. Czarnecka (2008) along the transect leading through three adjacent communities in the close vicinity to my study area: woodland, brushwood and grassland. The other noticeable change was overgrowing of low and loose xerothemic grassland by meadow and ruderal species, mainly Brachypodium pinnatum and Calamagrostis epigejos, which limited small-scale gaps named 'safe sites' (Harper 1977), 'regenerative niches' (Grubb 1977) or 'space free from competition' (Bullock 2000) necessary for seed germination and seedling establishment.

Taking into account the competitive features of Brachypodium pinnatum plants proposed by Grime (1973), that is, maximum plant height $(>100 \mathrm{~cm})$, genet morphology (forming tussocks attaining a diameter $>100 \mathrm{~cm}$ ), great maximum potential relative growth $\left(>8.0 \mathrm{mg} \cdot \mathrm{g}^{-1} \cdot \mathrm{h}^{-1}\right)$ and ability of accumulation of persistent - from one growing season to the next - continuous litter cover (necromass), it may be recognized as a highly competitive species. All the abovementioned traits facilitate spatial spreading of this and the other large-clonal grasses even to the state of monoculture and ensure successful competition with small-clonal or non-clonal species. Such invading abilities were also reported for species of the genus Calamagrostis occuring in different habitats: $C$. neglecta, $C$. canescens, $C$. epigejos and others (e.g. Kershaw 1962; Soukupová 1992; Rebele 2000; Březina et al. 2006; Somodi et al. 2008). Rhizomes and stolons provide clonal plants with the capacity of spatial mobility. In a heterogeneous environment, clones may be able to escape from adverse conditions and place ramets 


\section{A}

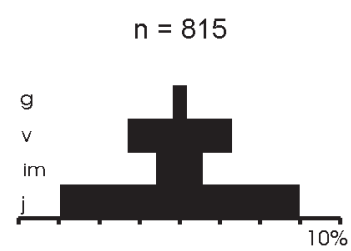

$\mathrm{n}=917$

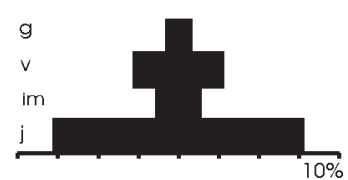

$\mathrm{n}=909$

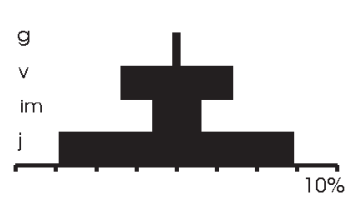

$\mathrm{n}=935$
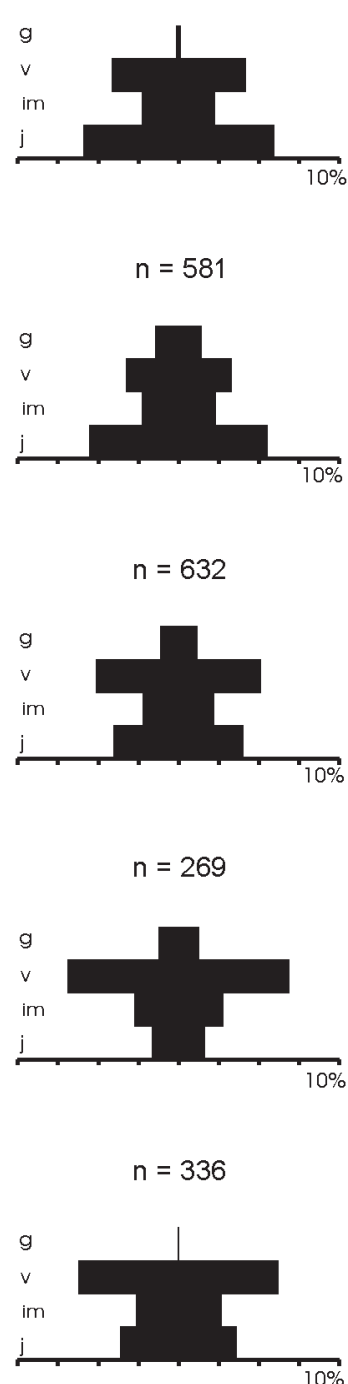

B

$\mathrm{n}=237$

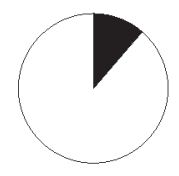

$\mathrm{n}=254$

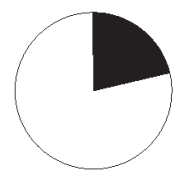

1992

$$
n=270
$$

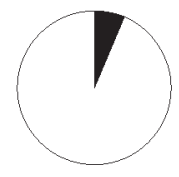

$\mathrm{n}=321$

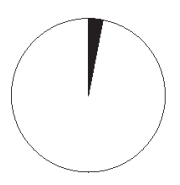

1998

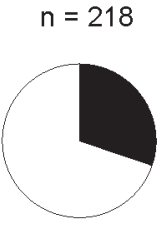

2001

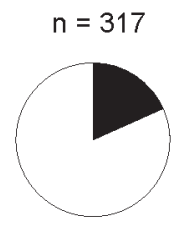

2002

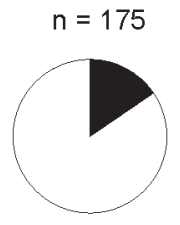

2003

$$
n=168
$$

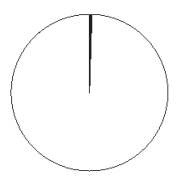

A

B

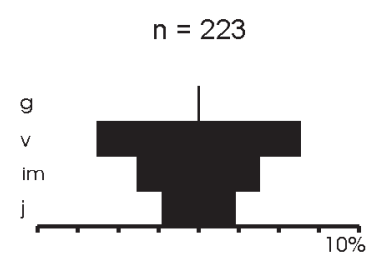

2004
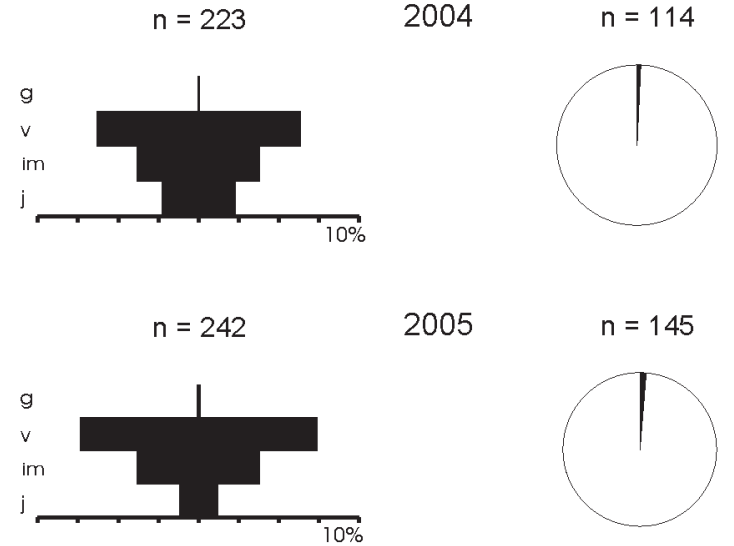

2005

$n=145$

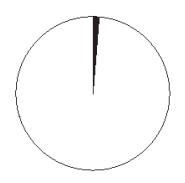

$n=197$

2006

$n=146$
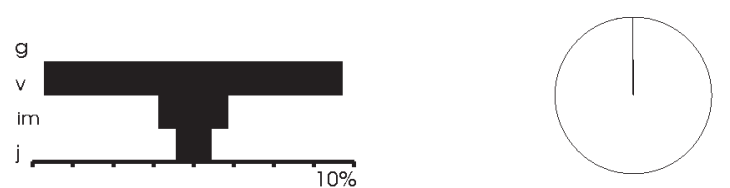

$n=76$
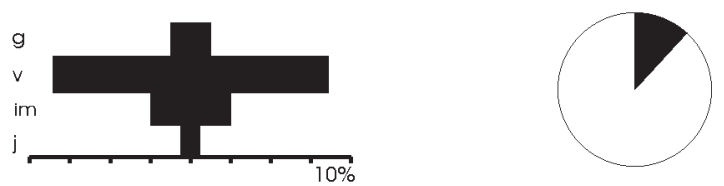

$n=79$

2008

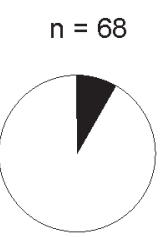

Fig. 2. Changes of the Senecio macrophyllus population at a small scale. Data collected within the permanent plot $\left(24 \mathrm{~m}^{2}\right)$. Remaining explanations as in Figure 1.

selectively in more favourable patches (de Kroon and Schieving 1990). This 'active foraging' increases with depletion of nutrients which causes exhausting of habitat resources (Grime 1988; Silvertown and Lovett Doust 1993; Kleijn and van Groenendael 1999; van Kleunen and Fischer 2001). The competitive abilities of clonal plants increase with their age and clumping (Blair 2001; Weiner 2004). For that reason Brachypodium pinnatum and other invasive grasses are responsible for reduction of floristic diversity of xerothermic grassland (Bobbink and Willems 1987; Dzwonko and Loster 1992; Hurst and John 1998; Bąba 2003; Loster and Gawroński 2005).

Brushwood overgrowing grassland diminish the area of open habitats but, on the other hand, this process may have a positive effect on the $S$. macrophyllus population. Trees and shrubs functioning as seed traps change the dispersal modes of the species. A similar role may be played by invading grasses, that form a tall and dense plant cover. Seed trapping is suggested by researchers who have found shor- 

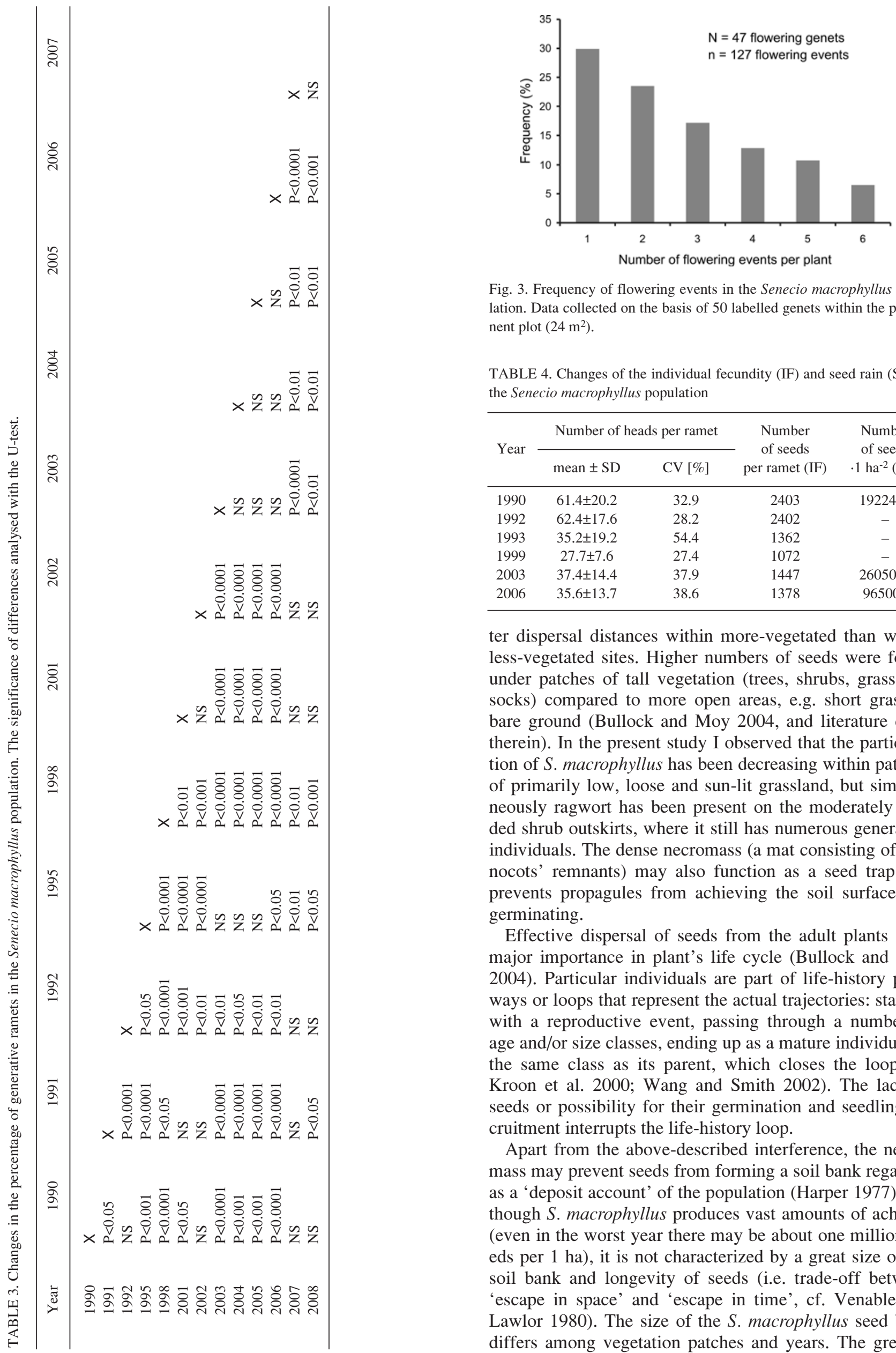

Fig. 3. Frequency of flowering events in the Senecio macrophyllus population. Data collected on the basis of 50 labelled genets within the permanent plot $\left(24 \mathrm{~m}^{2}\right)$.

TABLE 4. Changes of the individual fecundity (IF) and seed rain (SR) in the Senecio macrophyllus population

\begin{tabular}{|c|c|c|c|c|}
\hline \multirow{2}{*}{ Year } & \multicolumn{2}{|c|}{ Number of heads per ramet } & \multirow{2}{*}{$\begin{array}{c}\text { Number } \\
\text { of seeds } \\
\text { per ramet (IF) }\end{array}$} & \multirow{2}{*}{$\begin{array}{c}\text { Number } \\
\text { of seeds } \\
\cdot 1 \text { ha }^{-2}(\mathrm{SR})\end{array}$} \\
\hline & mean $\pm \mathrm{SD}$ & $\mathrm{CV}[\%]$ & & \\
\hline 1990 & $61.4 \pm 20.2$ & 32.9 & 2403 & 1922400 \\
\hline 1992 & $62.4 \pm 17.6$ & 28.2 & 2402 & - \\
\hline 1993 & $35.2 \pm 19.2$ & 54.4 & 1362 & - \\
\hline 1999 & $27.7 \pm 7.6$ & 27.4 & 1072 & - \\
\hline 2003 & $37.4 \pm 14.4$ & 37.9 & 1447 & 2605000 \\
\hline 2006 & $35.6 \pm 13.7$ & 38.6 & 1378 & 965000 \\
\hline
\end{tabular}

ter dispersal distances within more-vegetated than within less-vegetated sites. Higher numbers of seeds were found under patches of tall vegetation (trees, shrubs, grass tussocks) compared to more open areas, e.g. short grass or bare ground (Bullock and Moy 2004, and literature cited therein). In the present study I observed that the participation of S. macrophyllus has been decreasing within patches of primarily low, loose and sun-lit grassland, but simultaneously ragwort has been present on the moderately shaded shrub outskirts, where it still has numerous generative individuals. The dense necromass (a mat consisting of monocots' remnants) may also function as a seed trap that prevents propagules from achieving the soil surface and germinating.

Effective dispersal of seeds from the adult plants is of major importance in plant's life cycle (Bullock and Moy 2004). Particular individuals are part of life-history pathways or loops that represent the actual trajectories: starting with a reproductive event, passing through a number of age and/or size classes, ending up as a mature individual of the same class as its parent, which closes the loop (de Kroon et al. 2000; Wang and Smith 2002). The lack of seeds or possibility for their germination and seedling recruitment interrupts the life-history loop.

Apart from the above-described interference, the necromass may prevent seeds from forming a soil bank regarded as a 'deposit account' of the population (Harper 1977). Although S. macrophyllus produces vast amounts of achenes (even in the worst year there may be about one million seeds per $1 \mathrm{ha}$ ), it is not characterized by a great size of the soil bank and longevity of seeds (i.e. trade-off between 'escape in space' and 'escape in time', cf. Venable and Lawlor 1980). The size of the S. macrophyllus seed bank differs among vegetation patches and years. The greatest 
number of propagules established by the extraction method for the vegetation patch dominated by ragwort ranged from 251 to 1054 seeds $\cdot \mathrm{m}^{-2}$ in the years $1999-2001$, while seeds were absent in Brachypodium pinnatum and Aster amellus patches. During grassland overgrowing, the seed deposit in the soil decreased to only $61 \mathrm{seeds} \cdot \mathrm{m}^{-2}$ in 2004 . S. macrophyllus has a transient seed bank only. Its achenes are present in soil only during the short period between shedding and germination (Czarnecka and Czarnecka 2001; Czarnecka J. 2004, 2008). Therefore, the sufficiency of permanent flux of propagules is of great importance in species that do not form a persistent soil seed bank like $S$. macrophyllus.

In the light of long term studies I cannot unequivocally say that shrub encroachment and expansion of grasses are the only reasons for the decrease in the population abundance and reproductive potential. The limitation is realized on the population and genet levels, too. The life span of a genet, the frequency of flowering and fruiting episodes, and the number of produced generative ramets and propagules, all of which amount to individual fecundity, are measures of an individual contribution to the reproduction and in consequence the dynamics of a population (Harper 1977; Stearns 1992; Silvertown and Lovett Doust 1993; Hutchings 1997). In S. macrophyllus this contribution differs between fragments of the population area and between years (Czarnecka 1995, 2006). The decrease in the participation of genets and ramets in the reproductive phase was observed both at a large and small scale used in the reported study. As it was established on the basis of flowering frequency of marked genets, during the first period of the study (1989-2002) in the patches of low, loose and unshaded grassland, ragwort plants realized the flowering pattern of fluctuation character with higher proportion of generative ramets every three-four years (Czarnecka 2006). In the last seasons (since 2003) that pattern has been changing towards more and more chaotic (unpredictable), which was also confirmed by way of the example of all plants growing within the permanent study plot $\left(24 \mathrm{~m}^{2}\right)$. However, it does not have to be a result of environmental changes grassland overgrown by trees and shrubs, the increasing coverage of Brachypodium pinnatum and Calamagrostis epigejos or other meadow species, and other factors affected soil resources and microclimatic conditions. The significant decline in the $S$. macrophyllus population abundance, reproduction and seed rain seems to be caused by processes occurring on the genet level, too. Among others the most important are the following: a more advanced calendar age of genets with time (plant senescence), weakening of the biotic (reproductive) potential (i.e. trade-off between somatic growth and reproduction), resulting in lowering the share of generative ramets, frequency of reproductive episodes, individual fecundity, that is, the number of propagules per one reproductive episode, and in consequence a decrease in seed rain amounts.

The viable seed supply is determined by many other factors which can act in different periods of plant life. Sometimes plants lose the ability to produce effective propagules for biological reasons, which is described as genetic mortality, or it may happen that the habitat conditions, mainly climatic, prevent production of fertile seeds. At the stage of flowering, fruiting and seed dissemination, the amount of viable seeds is limited by different herbivores, granivores and pathogens, that is, vertebrates, invertebrates and fungi (e.g. Vorontzova and Zaugolnova 1985; Forbes 1993; Waser and Price 1998). Among the biotic factors that limit reproductive abilities of the $S$. macrophyllus population there is an exceptionally quick spread of phytopatogenic fungi. Among fungi species, mass appearance is characteristic for powder mildews (Erysiphales, Ascomycota), mainly Golovinomyces (= Erysiphe) cichoracearum (DC.) V.P. Gelyuta var. cichoracearum and rust (Uredinales, Basidiomycota) Coleosporium tussilaginis (Pers.) Berk. Sometimes anamorphic fungi (= Fungi imperfecti) are also abundant, e.g. Phyllosticta senecionicola, Ph. jacobaeae and Septoria sp. (leg. B. Czarnecka, det. A. Wołczańska). It has been observed since the early 2000-ties that in some years S. macrophyllus does not produce valuable propagules both in the natural condition and in experimental garden (B. Czarnecka, unpbl. data).

To establish a new generation of genets, sufficiency of safe sites is also required. I cannot unequivocally state that small-scale openings in close limestone grasslands are the most important factor affecting seedling appearance, and if so, how large gaps ought to be (Bąba and Kompała-Bąba 2005, and literature cited therein). Seedlings of S. macrophyllus may occur in small numbers all the growing seasons. In some years two seasonal kohorts occur: in spring and in autumn, the latter being much smaller. In the year of the greatest appearance - 1991 - seedling density in the area of permanent transect differed between 468 and 600 seedlings $\cdot \mathrm{m}^{-2}$ (Czarnecka 1995). At the height of the same season 'seedling rain' established along the slope-gradient line transect, then, illustrated various microhabitats, took values from the range $68-600$ seedlings $\cdot \mathrm{m}^{-2}$ (B. Czarnecka, unpbl. data). Ten years later, in spring 2001, J. Czarnecka (2004) counted seedlings emerging in 10 randomly distributed squares $\left(100 \mathrm{~cm}^{-2}\right.$ each) within two contrasting parts of patch dominated by ragwort: a shaded, more humid, on the outskirt of brushwood, and unshaded, which was strongly desiccated from early spring. Seedling numbers calculated on that basis were 2070 and $70 \cdot \mathrm{m}^{-2}$, respectively. Although the seedling number within the shaded microplots seems to be overcalculated (maybe for the small spatial scale adopted), the results confirmed my earlier observations on the importance of proper soil moisture and structure, group dispersal near the parent plants, as well as mature plants 'nurse effect' for seedling appearance and juvenile establishment (Czarnecka 1995, 1998). The observed continuous decreasing of share of juveniles within the permanent study plot until the absence of that life stage points to interruption of recruitment of new genets into some parts of the population. Fortunately, young individuals are still present in other microhabitats, which was confirmed along the line transect and other observations.

Despite the weakening of recruitment of new generative genets, variation in flowering frequency between subsequent years, as well as relatively low seed germinability, and very low seedling recruitment rate (Czarnecka 1995, 2006; B. Czarnecka, unpbl. data), even occasional sexual reproduction might enrich the genetic variation of the S. macrophyllus population. The recent study indicates that the population produces enough offspring to be self-sustaining and it has a heterogeneous genetic structure with values of heterozygosity $(\mathrm{H})$ amounting to 0.853 (Czarnecka and Ptaszyńska 2008). However, when populations of plants 
occur in a small geographic area, like in the case of S. macrophyllus, they are extremely vulnerable to local disturbances or catastrophes (Hamrick and Godt 1989). For that reason, monitoring of the population is still necessary.

\section{ACKNOWLEDGEMENTS}

I would like to thank my co-workers Mrs. Krystyna Kowalska and Mrs. Anna Majewska for their help in technical work, and Dr. Joanna Czarnecka for statistical analysis. My thanks go also to Dr. Agata Wołczańska who identified fungi taxa, and to Mrs. Anna Wesołowska-Zoń who improved my English.

\section{LITERATURE CITED}

BĄBA W. 2003. Changes in the structure and floristic composition of the limestone grasslands after cutting trees and shrubs and mowing. Acta Soc. Bot. Pol. 72: 61-69.

BABA W., KOMPAŁA-BABAA A. 2005. Do small-scale gaps in calcareous grassland swards facilitate seedling establishment? Acta Soc. Bot. Pol. 74: 125-131.

BEGON M., TOWSEND C.R., HARPER J.L. 2008. Ecology: from individuals to ecosystems. 4th ed. Blackwell Publ., Oxford.

BLAIR B. 2001. Effect of soil nutrient heterogeneity on the symmetry of belowground competition. Plant Ecol. 156: 199-203.

BOBBINK R., WILLEMS J.H. 1987. Increasing dominance of Brachypodium pinnatum (L.) Beauv. in chalk grasslands. Biol. Conserv. 40: 301-314.

BŘEZINA S., KOUBEK T., MÜNZBERGOVÁ Z., HERBEN T. 2006. Ecological benefits of integration of Calamagrostis epigejos ramets under field conditions. Flora 201: 461-467.

BULLOCK J.M. 2000. Gaps and seedling colonization. In: Fenner M. (ed.). Seeds. The ecology of regeneration in plant communities. 2nd ed. CAB International, pp. 375-395.

BULLOCK J.M., MOY I.L. 2004. Plants as seed traps: inter-specific interference with dispersal. Acta Oecol. 25: 35-41.

CHATER A.O., WALTERS S.M. 1976. Senecio L. In: Tutin T.G., Heywood V.H., Burges N.A, Moore D.M., Valentine D.H., Walters S.N., Webb D.A. (eds). Flora Europaea 4, Univ. Press, Cambridge, pp. 191-205.

CRAWLEY M.J. 1990. The population dynamics in plants. Phil. Trans. Royal Soc. London B 330: 125-140.

CZARNECKA B. 1994. Zbiorowiska Białej Góry koło Tomaszowa Lubelskiego jako siedlisko rzadkich roślin naczyniowych. Chrońmy Przyr. Ojcz. 50: 16-22. (in Polish with English summary)

CZARNECKA B. 1995. Biologia i ekologia izolowanych populacji Senecio rivularis (Waldst. et Kit.) DC. and Senecio umbrosus Waldst. et Kit. Wyd. UMCS, Lublin (in Polish with English summary).

CZARNECKA B. 1998. Gaps and neighbours versus individual recruitment in population. In: Falińska K. (ed.). Plant population biology and vegetation processes. Polish Acad. Sci., W. Szafer Inst. Botany, Kraków, pp. 289-301.

CZARNECKA B. 2006. Large-scale vs. small-scale factors affecting flowering patterns in Senecio macrophyllus M.BIEB., a long-lived perennial. Acta Agrobot. 59: 233-239.

CZARNECKA B., KUCHARCZYK M., MIREK Z. 1993. Senecio umbrosus Waldst. et Kit. - starzec cienisty. In: Zarzycki K., Kaźmierczakowa R. (eds). Polska czerwona księga roślin. Paprotniki i rośliny kwiatowe. PAN, Inst. Bot. im. W. Szafera, Inst. Ochr. Przyr., Kraków, pp. 186-187. (in Polish)

CZARNECKA B., KUCHARCZYK M. 2001. Senecio macrophyllus M. BIEB. - starzec wielkolistny. In: Zarzycki K., Ka- źmierczakowa R. (eds). Polska czerwona księga roślin. Paprotniki i rośliny kwiatowe. PAN, Inst. Bot. im. W. Szafera, Inst. Ochr. Przyr., Kraków, pp. 375-377. (in Polish with English summary)

CZARNECKA B., PTASZYŃSKA A. 2008. Genetic diversity within the island population of Senecio macrophyllus M.BIEB. (Asteraceae), a vulnerable species in Poland. Scripta Facult. Rerum Natur. Univ. Ostraviensis 186: 231-235.

CZARNECKA J. 2004. Seed longevity and recruitment of seedlings in xerothermic grassland. Pol. J. Ecol. 52: 505-521.

CZARNECKA J. 2008. Spatial and temporal variability of seed bank resulting from overgrowing of xerothermic grassland. Acta Soc. Bot. Pol. 77: 157-166.

CZARNECKA J., CZARNECKA B. 2001. The role of a seed bank in the maintenance of valuable components of xerothermic grassland. Ekologia (Bratislava) 20, Suppl. 4: 215-221.

DZWONKO Z., LOSTER S. 1992. Zróżnicowanie roślinności i wtórna sukcesja w murawowo-leśnym rezerwacie Skołczanka koło Krakowa. Ochr. Przyr. 50: 33-64. (in Polish with English summary)

FALIŃSKA K. 1998. (ed.). Plant population biology and vegetation processes. Polish Acad. Sci., W. Szafer Inst. Botany, Kraków.

FORBES M.R.L. 1993. Parasitism and host reproductive effort. Oikos 67: 444-450

GATSUK L.E., SMIRNOVA O.V., VORONTZOVA L.I., ZAUGOLNOVA L.B., ZHUKOVA L.A. 1980. Age states of plant of various growth forms, a review. J. Ecol. 68: 675-696.

GRIME J.P. 1973. Competitive exclusion in herbaceous vegetation. Nature 242: 344-347.

GRIME J.P. 1988. The C-S-R model of primary strategies - origins, implications and tests. In: Gottlieb L.D., Jain S.K. (eds. ). Plant evolutionary biology. Chapman and Hall, New York, pp. 371-393.

GRUBB P.J. 1977. The maintenance of species-richness in plant communities: the importance of the regeneration niche. Biol. Rev. 52: 107-145.

GRULICH V., HODÁLOVA I. 1994. Senecio doria group (Asteraceae-Senecioneae) in Central and Southeastern Europe. Phyton 34: 247-265.

HAMRICK J.L., GODT M.J.W. 1989. Allozyme diversity in plant species. In: Brown A.H.D., Clegg M.T., Weir B.S. (eds). Plant population genetics, breeding, and genetic resource. Sinauer Ass., Sunderland, Massachusetts, pp. 43-63.

HARA T. 1988. Dynamics of size structure in plant populations. Trends Ecol. Evol. 3: 129-133.

HARPER J.L. 1977. Population biology of plants. Acad. Press, London.

HUTCHINGS M.J. 1997. The structure of plant populations. In: Crawley M.J. (ed.). Plant ecology. 2nd ed. Blackwell Sci., Oxford, pp. 325-358.

HURST A., JOHN E. 1998. The biotic and abiotic changes assiociated with Brachypodium pinnatum dominance in chalk grassland in South-East England. Biol. Conserv. 88: 75-84.

KERSHAW K.A. 1962. Quantitative ecological studies from Landmannahellir, Iceland. II. The rhizome behaviour of Carex bigelowii and Calamagrostis neglecta. J. Ecol. 50: 171-179.

KLEIJN D., GROENENDAEL van J.M. 1999. The exploatation of heterogeneity by a clonal plant in habitats with contrasting productivity levels. J. Ecol. 87: 873-884.

KLEUNEN van M., FISCHER M. 2001. Adaptive evolution of plastic foraging responses in a clonal plant. Ecology 82: 3309-3319 .

KROON de H., SCHIEVING F. 1990. Resource partitioning in relation to clonal growth strategy. In: van Groenendael J., de Kroon H. (eds). Clonal growth in plants: regulation and functions. SPB Acad. Publ., The Hague, pp. 113-130.

KROON de H., GROENENDAEL van J., EHRLEN J. 2000. Elasticities: a review of methods and model limitations. Ecology 81: 607-618. 
KWIATKOWSKA A.J., SYMONIDES E. 1978. Metody pomiaru zagęszczenia populacji roślin wyższych. Wiad. Ekol. 24: 127143. (in Polish with English summary)

LOSTER S., GAWROŃSKI S. 2005. Przemiany nawapiennej murawy w rezerwacie "Biała Góra" (Wyżyna Miechowska, południowa Polska) w ciągu ostatnich 80 lat. Fragm Flor. Geobot. Polonica 12: 301-315. (in Polish with English summary)

MATUSZKIEWICZ W. 2005. Przewodnik do oznaczania zbiorowisk roślinnych Polski. Wyd. Nauk. PWN, Warszawa. (in Polish)

MIREK Z., PIĘKOŚ-MIRKOWA H., ZAJĄC A., ZAJĄC M. 2002. Vascular plants of Poland: a checklist, Biodiversity of Poland 1, Polish Acad. Sci., Kraków.

PICKETT S.T.A., WHITE P.S. 1985. (eds). The ecology of natural disturbance and patch dynamics. Academic Press, New York

REBELE F. 2000. Competition and coexistence of rhizomatous perennial plants along a nutrient gradient. Plant Ecol. 147: 77$-94$.

SILVERTOWN J.W., LOVETT DOUST J. 1993. Introduction to plant population biology. 3rd ed. Blackwell Sci., Oxford.
SOMODI I., VIRÁGH K., PODANI J. 2008. The effect of the expansion of the clonal grass Calamagrostis epigejos on the species turnover of the semi-arid grassland. Appl. Veg. Sci. 11: 187-192.

SOUKUPOVÁ L. 1992. Calamagrostis canescens: population biology of clonal grass invading wetlands. Oikos 63: 395-401.

STEARNS S.C. 1992. The evolution of life histories. Oxford Univ. Press, Oxford.

VENABLE D.L., LAWLOR L. 1980. Delayed germination and dispersal in desert annuals: escape in space and time. Oecologia 46: 272-282.

VORONTZOVA L.I., ZAUGOLNOVA L.B. 1985. Population biology of steppe plants. In: White J. (ed.). The population structure of vegetation. Dr W. Junk Publ., Dordrecht, pp. 143-178 .

WANG B.C., SMITH T.B. 2002. Closing the seed dispersal loop. Trends Ecol. Evol. 17: 379-386.

WASER N.M., PRICE M.V. 1998. What plant ecologists can learn from zoology. Persp. Plant Ecol. Evol. Syst. 1-2: 137-150.

WEINER J. 2004. Allocation, plasticity and allometry in plants. Persp. Plant Ecol. Evol. Syst. 6: 207-215. 